\title{
Constraints as Perceived by the Members in Availing Services of Cooperative Societies in South Gujarat
}

\author{
M. V. Chaudhary*, O. P. Sharma and K. L. Chaudhary \\ ${ }^{1}$ Department of Extension and Communication, NMCA, NAU, Navsari -396450, India \\ ${ }^{2}$ Department Social Science, ASPEE College of Horti. \& Forestry, NAU, \\ Navsari-396450, India \\ ${ }^{3}$ Department of Extension Education, NMCA, NAU, Navsari -396450, India \\ *Corresponding author
}

\section{A B S T R A C T}

Keywords

Constraints,

Cooperative

societies, South

Gujarat

Article Info

Accepted:

15 December 2020

Available Online:

10 January 2021
The present study was conducted in South Gujarat. And total 280 respondent cooperative society members were selected from all seven district of South Gujarat. The major constraints faced by cooperative society members were "Non availability of timely credit" followed by Irregular or non-availability of medical facility for dairy animals, Higher cost of fertilizers/weedicides/fungicides, Delay in payments by the cooperative societies". And "Non-availability of fertilizers in required quantity", "High cost of transportation and poor transportation facilities", "Non-availability of recommended seed for timely sowing", "Lack of training facility for cooperatives members regarding improved agriculture and livestock practices"

\section{Introduction}

The co-operatives have been playing pivotal role in our agricultural and rural economy. They are engaged in several economic activities such as disbursement of credit, distribution of agricultural inputs like; seeds, fertilizers, and agro-chemicals for plant protection, arranging storage, processing and marketing of farm produce. Co-operatives enable farmers in getting good quality inputs at a reasonable price as well as in getting remunerative returns for their farm produce when marketed through them. The cooperative agro-processing units add value to their farm produce such as milk, sugarcane, cotton, fruits and vegetables and thus facilitate and ensure better returns.

During the nineties, with the initiation of new economic policies, the sector was not given the importance which it deserved. Ghosh (1994) rightly observed that the new economic policy favours foreign capital and large business and finance capital but they are still as rigid and restrictive as ever for co- 
operatives and genuinely democratic alternative organizations. Whereas, their importance has increased as our resource poor farmers have to compete with their resource rich counter parts. Co-operatives build capacity and empower the farmers. Keeping the facts in view the present study entitled, "Constraints as Perceived by the Members in availing Services of Cooperative Societies in South Gujarat" was undertaken.

\section{Materials and Methods}

The present investigation was conducted in all seven districts of South Gujarat. and all seven districts of south Gujarat were selected for study. from each selected talukas two cooperative societies were selected and from each selected cooperative societies 10 respondent members were selected for study. Thus, total 280 respondents were selected for study. Ex-post facto research design was used for present investigation. The researchers collected data by using personal interview schedule method. The collected data were analyzed by using appropriate statistical tools like: Frequency and Percentage and ranking of constraints was done accordingly to draw the inferences.

\section{Results and Discussion}

The data presented in table 1 indicated that out of ten perceived constraints; Non availability of timely credit (88.57 per cent) was reported as a major constraint by the respondent cooperative society members and ranked at first posit followed by Irregular or non-availability of medical facility for dairy animals (86.43 per cent),Higher cost of fertilizers/weedicides/fungicides(78.57 per cent), Delay in payments by the cooperative societies (76.43 per cent), Non-availability of fertilizers in required quantity (66.43 per cent) which were ranked at second, third, fourth and fifth position according to respondent cooperative members. Moreover, constraints like; High cost of transportation and poor transportation facilities (65.71 per cent), Non-availability of recommended seed for timely sowing (60.71 per cent), Lack of training facility for cooperatives members regarding improved agriculture and livestock practices (56.42 per cent), Shortage of labour during peak season (55.71 per cent) and Not getting remunerative price for produce (53.57 per cent) were ranked at sixth, seventh, eighth, ninth and tenth rank, respectively.

Table.1 Distribution of the respondents according to constraints as perceived by them in socioeconomic development $(n=280)$

\begin{tabular}{|c|l|c|c|c|}
\hline Sr & \multicolumn{1}{|c|}{ Constraints } & Frequency & Percentage & Rank \\
\hline $\mathbf{1 .}$ & Irregular or non-availability of medical facility for dairy animals. & 242 & 86.43 & II \\
\hline $\mathbf{2 .}$ & Delay in payments by the cooperative societies. & 214 & 76.43 & IV \\
\hline $\mathbf{3}$ & Higher cost offertilizers/weedicides/fungicides. & 220 & 78.57 & III \\
\hline $\mathbf{4 .}$ & Non availability of timely credit. & 248 & 88.57 & I \\
\hline $\mathbf{5 .}$ & Non-availability of recommended seed for timely sowing. & 170 & 60.71 & VII \\
\hline $\mathbf{6 .}$ & Non-availability of fertilizers in required quantity. & 186 & 66.43 & V \\
\hline $\mathbf{7 .}$ & High cost of transportation and poor transportation facilities. & 184 & 65.71 & VI \\
\hline $\mathbf{8 .}$ & Shortage of labour during peak season. & 156 & 55.71 & IX \\
\hline 9. & Not getting remunerative price for produce. & 150 & 53.57 & X \\
\hline $\mathbf{1 0 .}$ & $\begin{array}{l}\text { Lack of training facility for cooperatives members regarding } \\
\text { improved agriculture and livestock practices. }\end{array}$ & 158 & 56.42 & VIII \\
\hline
\end{tabular}


According to above findings, it may be concluded that major constraint faced by cooperative society members were "Non availability of timely credit" "Irregular or non-availability of medical facility for dairy animals" and"Higher cost of fertilizers/weedicides/fungicides" and major suggestions were "Credit availability whenever needed must be ensured", "Timely availability of medical facility should be ensured" and "Timely payment for produce must be done".

\section{References}

Kalsariya, B. N., Rankja, N. J. and Gorfad, P. S. (2018). Constraints faced and suggestion offered by farmers in accessing the required information through SMS and voice messages. Guj. J. Ext. Edu., 29:99-101.

Ghosh Jayati (1994). Gender concerns in macroeconomic policy. Economic and political weekly, 29 (18): 30.

Bardhan. D., Srivastav, R. S. L. and Dabas, Y. P. S. (2005). A study on constraintsperceived by farmers in rearing dairy animals. Indian Journal of Dairy Science. 58 (3): 241-218.

\section{How to cite this article:}

Chaudhary, M. V., O. P. Sharma and Chaudhary, K. L. 2021. Constraints as Perceived by the Members in Availing Services of Cooperative Societies in South Gujarat. Int.J.Curr.Microbiol.App.Sci. 10(01): 2376-2378.

doi: https://doi.org/10.20546/ijcmas.2021.1001.275 